\title{
The prognostic value of clinical characteristics and parameters of cerebrospinal fluid hydrodynamics in shunting for idiopathic normal pressure hydrocephalus
}

\author{
E. J. Delwel, D. A. de Jong, and C. J. J. Avezaat [Acta Neurochir (Wien) (2005) 147: 1037-1043]. \\ DOI 10.1007/s00701-005-0570-y
}

On page 1042 the reference list as below was missing.

\section{References}

1. Albeck MJ, Børgesen SE, Gjerris F, Schmidt JF, Sørensen SL (1991) Intracranial pressure and cerebrospinal fluid outflow conductance in healthy subjects. J Neurosurg 74: 597-600

2. Avezaat CJJ, van Eijndhoven JHM, Wyper DJ (1979) Cerebrospinal fluid pulse pressure and intracranial volume-pressure relationships. J Neurol Neurosurg Psychiatry 42: 687-700

3. Bech RA, Juhler M, Waldemar G, Klinken L, Gjerris F (1997) Frontal brain and leptomeningeal biopsy specimen correlated with cerebrospinal fluid outflow resistance and B-wave activity in patients suspected of normal pressure hydrocephalus. Neurosurgery 40(3): 497-502

4. Belloni G, di Rocco C, Focacci C, Galli G, Maira G, Rossi GF (1976) Surgical indications in normotensive hydrocephalus. A retrospective analysis of the relation of some diagnostic findings to the results of surgical treatment. Acta Neurochir (Wien) 33: 1-21

5. Benzel EC, Pelletier AL, Levy PG (1990) Communicating hydrocephalus in adults: prediction of outcome after ventricular shunting procedures. Neurosurgery 26: 655-660

6. Black P (1980) Idiopathic normal pressure hydrocephalus. Results of shunting in 62 patients. J Neurosurg 52: 371-377

7. Boon AJW, Tans JThW, Delwel EJ, Egeler-Peerdeman SM, Hanlo PW, Wurzer HAL, Avezaat CJJ, de Jong DA, Gooskens RHJM, Hermans J (1997) Prediction of outcome after shunting by resistance to outflow of cerebrospinal fluid. J Neurosurg 87: 687-693

8. Børgesen SE, Gjerris F, Sørensen SC (1978) The resistance to cerebrospinal fluid absorption in humans. Acta Neurol Scand 57: 97-140

9. Børgesen SE, Gjerris FM, Sørensen MD (1979) Cerebrospinal fluid conduction and compliance of the craniospinal space in normal pressure hydrocephalus. J Neurosurg 51: 521-525

10. Børgesen SE, Gjerris F (1982) The predictive value of conductance to outflow os CSF in normal pressure hydrocephalus. Brain 105: $65-86$

11. Børgesen SE (1984) Conductance to outflow of CSF in normal pressure hydrocephalus. Acta Neurochir (Wien) 71: 1-45

12. Børgesen SE (1985) Conductance to outflow of CSF in normal pressure hydrocephalus. Acta Neurochir (Wien) 71: 1-45

13. Bradley WG, Whittemore AR, Watanabe AS, Davis SJ, Teresi LM, Homyak M (1991) Association of deep white matter infarction with chronic communicating hydrocephalus: implications regarding the possible origin of normal pressure hydrocephalus. AJNR 12: 31-39

14. Corkill RG, Cadoux-Hudson TAD (1999) Normal pressure hydrocephalus: developments in determining surgical prognosis. Curr Opin Neurol 12: 671-677

15. De Jong DA, Delwel EJ, Avezaat CJJ (2000) Hydrostatic and hydrodynamic considerations in shunted normal pressure hydrocephalus. Acta Neurochir (Wien) 142: 241-247

16. Graff-Redford NR, Godersky JC, Jones MP (1989) Variables predicting surgical outcome in symptomatic hydrocephalus in the elderly. Neurology 39: 1601-1604

17. Greenberg JO, Shenkin HA, Adam R (1977) Idiopathic normal pressure hydrocephalus - a report of 73 patients. J Neurol Neurosurg Psychiatry 40: 336-341

18. Hakim C (1985) The physics and physicopathology of the hydraulic complex of the central nervous system. Thesis, Massachusetts Institute of Technology, Cambridge

19. Hakim S, Adams RD (1965) The special clinical problem of symptomatic hydrocephalus with normal cerebrospinal fluid pressure. Observations on cerebrospinal fluid hydrodynamics. J Neurol Sci 2: 307-327

20. Hughes CP, Siegel BA, Coxe WS, Gado MH, Grubb RL, Coleman RE, Berg L (1978) Adult idiopathic communicating hydrocephalus with and without shunting. J Neurol Neurosurg Psychiatry 41: 961-971

21. Katzman R, Hussey F (1970) A simple constant-infusion manometric test for measurement of CSF absorption. Neurology 20: 534-544

22. Kimura M, Tanake A, Yoshinaga S (1992) Significance of periventricular hemodynamics in normal pressure hydrocephalus. Neurosurgery 30(5): 701-705

23. Kosteljanetz M, Nehen AM, Kaalund J (1990) Cerebrospinal fluid outflow resistance measurements in the selection of patients for shunt surgery in the Normal Pressure Hydrocephalus syndrome. A controlled trial. Acta Neurochir (Wien) 104: 48-53

24. Krauss JK, Regel JP, Vach W, Droste DW, Borremans JJ, Meigner T (1996) Vascular risk factors and arteriosclerotic disease in idiopathic normal-pressure hydrocephalus of the elderly. Stroke 27(1): 24-29

25. Kristensen B, Malm J, Fagerlund M, Hietala S-O, Johansson B, Ekstedt J, Karlsson T (1996) Regional cerebral blood flow, white matter abnormalities, and cerebrospinal fluid hydrodynamics in patients with idiopathic adult hydrocephalus syndrome. J Neurol Neurosurg Psychiatry 60: 282-288 
26. Kuschner M, Younkin D, Weinberger J, Hutig H, Goldberg H, Reivich M (1984) Cerebral hemodynamics in the diagnosis of normal pressure hydrocephalus. Neurology (Cleveland) 34: 96-99

27. Lamas E, Lobato RD (1979) Intraventricular pressure and CSF dynamics in chronic adult hydrocephalus. Surg Neurol 12: 287-295

28. Larsson A, Wikkelsö C, Bilting M, Stephensen H (1991) Clinical parameters in 74 consecutive patients shunt operated for normal pressure hydrocephalus. Acta Neurol Scand 84: 475-482

29. Larsson A, Jensen Ch, Bilting M, Ekholm S, Stephensen H, Wikkelsö C (1992) Does the shunt opening pressure influence the effect of shunt surgery in normal pressure hydrocephalus? Acta Neurochir (Wien) 117: 15-22

30. Larsson A, Bergh A-C, Bilting M, Ärlig Å, Jacobsson L, Stephensen H, Wikkelsö C (1994) Regional cerebral blood flow in normal pressure hydrocephalus: diagnostic and prognostic aspects. Eur J Nucl Med 21(2): 118-123

31. Lundar T, Nornes H (1990) Determination of ventricular fluid outflow resistance in patients with ventriculomegaly. J Neurol Neurosurg Psychiatry 53: 896-898

32. Malm J, Fagerlund M, Koskinen LO, Ekstedt J (1995) Cerebrospinal fluid shunt dynamics in patients with idiopathic adult hydrocephalus syndrome. J Neurol Neurosurg Psychiatry 58: 715-723

33. Marmarou A (1973) A theoretical model and experimental evaluation of the cerebrospinal fluid system. Thesis, Drexel University

34. Marmarou A, Shulman K, LaMorgese J (1975) Compartmental analysis of compliance and outflow resistance of the cerebrospinal fluid system. J Neurosurg 43: 523-534

35. Matsuda M, Takayama S, Matsumura K, Handa J (1987) Postsurgical disappearance of dementia without increased cerebral blood flow in hydrocephalic patients. Neurol Med Chir (Tokyo) 27: $24-30$

36. Matsuda M, Nakasu S, Nakazawa T, Handa J (1990) Cerebral hemodynamics in patients with normal pressure hydrocephalus: correlation between cerebral circulation time and dementia. Surg Neurol 34: 396-401
37. Meyer JS, Tachibana H, Hardenberg JP, Dowell RE, Kitagawa Y, Mortel KF (1984) Normal pressure hydrocephalus. Influences on cerebral hemodynamic and cerebrospinal fluid pressure-Chemical autoregulation. Surg Neurol 21: 195-203

38. Petersen RC, Mokri B, Laws ER (1985) Surgical treatment of idiopathic hydrocephalus in elderly patients. Neurology 35 : 307-311

39. Pudenz RH, Foltz EL (1991) Hydrocephalus: overdrainage by ventricular shunts. A review and recommendations. Surg Neurol 35: $200-212$

40. Sahuquillo J, Rubio E, Codina A, Molins A, Guitart JM, Poca MA, Chasampi A (1991) Reappraisal of the intracranial pressure and cerebrospinal fluid dynamics in patients with the so-called "Normal Pressure Hydrocephalus" syndrome. Acta Neurochir (Wien) 112: 50-61

41. Samuelson S, Long DM, Chou SN (1972) Subdural hematoma as a complication of shunting procedure for normal pressure hydrocephalus. J Neurosurg 37: 548-551

42. Tans JTJ (1979) Differentiation of normal pressure hydrocephalus and cerebral atrophy by computed tomography and spinal infusion test. J Neurol 222: 109-118

43. Tans JTJ, Poortvliet DCJ (1985) CSF outflow resistance and pressure volume index determined by steady state and bolus infusion. Clin Neurol Neurosurg 87: 159-165

44. Vanneste JAL (1991) General introduction and review of the literature. In: Vanneste JAL (ed) Studies in normal pressure hydrocephalus. Rodopi press: Amsterdam, pp 1-31

45. Vanneste JAL, Augustijn P, Dirven C, Tan WF, Goedhart ZD (1992) Shunting normal pressure hydrocephalus: do the benefits outweigh the risks? A multicentre study and literature review. Neurology 42 : 54-59

46. Vanneste JAL (1994) Three decades of normal pressure hydrocephalus: Are we wiser now? J Neurol Neurosurg Psychiatry 57: 1021-1025

47. Vorstrup S, Christensen J, Gjerris F, Sørensen PS, Thomsen AM, Paulsen OB (1987) Cerebral blood flow in patients with normal pressure hydrocephalus before and after shunting. J Neurosurg 66: 379-387 